\title{
LEGAL POSSIBILITY TO REGULATE DEFENSIVE MARK AS WELL-KNOWN MARK PROTECTION IN INDONESIA
}

\author{
Renggi Ardya Putra, SH \\ Alumni Fakultas Hukum Universitas Islam Indonesia
}

Contact: renggiap@gmail.com

Recieved: 29 Juni 2018

Revised: 13 Agustus 2018

Accepted: 15 Agustus 2018

Copyright: (C) 2018

Pages: 1 - 12

\begin{abstract}
Tingkat pelanggaran terhadap merek terkena dan merek termasyhur di Indonesia masih terbilang tinggi yang mana tindakan tersebut dilakukan pihak yang tidak memiliki hak yang digunakan untuk menjalankan bisnis dengan cara persaingan usaha yang tidak sehat di Indonesia. Hal tersebut berdampak pada timbulnya kesesatan dan kebingungan (likelihood of confussion) di masyarakat. Perlindunagan merek terkenal/termasyhur diatur dalam hukum internasional dan hukum nasional. Dalam hukum internasional, diatur dalam Paris Convention on Industrial Property dan Trade Related Aspect of Intellectual Property Rights (TRIPs). Selain itu, Organisasi Kekayaan Intelektual Dunia (WIPO) mengeluarkan Rekomendasi WIPO tentang Ketentuan tentang Perlindungan Merek terkenal. WIPO Recommendation on Provision on Protection of well-known Mark. Selain itu, Negara-negara memiliki independensi untuk memberlakukan ketentuan tentang perlindungan merek terkenal dengan undang-undang nasional. Salah satu jenis perlindungan adalah dengan mendaftarkan tanda ke pendaftaran merek defensive (Defensive Mark). Merek Defensif merupakan perlindungan yang tidak umum di dunia. Indonesia secara tidak langsung melindungi merek defensif. Faktor yang menghambat pemberlakuan merek defensif di Indonesia adalah ketidaksiapan merek local. Di sisi lain, pemberlakuan merek defensive di Indonesia akan meningkatkan kriminalisasi dan gugatan perdata terhadap merek lokal, karena perlindungan hukum terhadap pihak asing yang memperoleh merek terkenal atau merek terkenal dapat mengajukan gugatan dan penuntutan terhadap merek lokal yang tidak memiliki perlindungan merek dagang. Sehingga dapat menghambat pertumbuhan ekonomi di Indonesia, Hal itu membuat tanda defensif tidak mungkin diatur di Indonesia. Selain itu, kesadaran untuk mendaftarkan merek dagang di Indonesia masih rendah. Hal itu tercermin dengan pendaftaran merek dagang di Indonesia yang masih rendah jumlahnya.
\end{abstract}

Keywords: Kemungkinan Hukum, Merek Defensif, Perlindungan Merek terkenal dan termasyhur

\section{INTRODUCTION}

In this era, trademark is not only known as one of rights but also trademark is recognized as intangible assets which become the most important thing, and, in some cases, it is considered as most valuable assets of several companies. The development of business activity and advertisement and information technology and Globalization create mark as one of the instruments by business actors to promote and distribute their products both at national and international levels within cross-border and global commerce. Trademark has taken on a new and highly valuable significance asset. (Collin, 2014: 210)

Goods and/or services that are produced by a company will have good reputation if it is acknowledged by general acknowledgement peoples by the existence of trademark. 
High level of reputation mark is known by people in the relevant sector called as well-known mark. By designing a product of goods and/or services into a well-known mark or high-level mark, it can generate multiple profits for producers or business actors and enhance the reputation of product between societies. In addition, well-known marks also will win business competition fairly among business competitors. In globalization era, along with the flow of investment capital from developed countries to developing and less developed countries, well-known or famous trademark are also exported to developed domestic markets. (Tam, 2011: 66)

As the development of business activity and consumers' loyalty designed by reputation of mark can affect mark infringement at national and international levels. (Rizaldi, 2009: 4) Frederick W Moestert mentioned that: (W.Mostert, 1997: 5)

"In such a smaller but more intensely networked world, brand manufactures are no longer confined to local markets. They function in an integrated global marketplace. Brand products find themselves providing goods and services in bigger and bigger markets created by free trade pacts and the creation of single markets throughout the world. Against the reality of this background, there is certainly no doubt in the minds of business persons that the reputation and goodwill attached to their brands have become detached from national and local borders."

By statements above, he argued that there is spread of product trade of well-known mark which cross border commerce. Basically, it is not only to maintain quality of product, but also maintain the reputation or goodwill of well-known mark used by consumers around the world. The infringements of well-known marks are not only from origin country, but also come from other countries.

For that reason, trademark especially well-known mark should be protected by the law namely trademark law whether at national level and International level. At national level there are different types of trademark protection which vary from country to country. It caused by trademark rights principle that are territorial rights means they are protected only by the law of the country by its domestic trademark law. This difference is apparent in many aspects of trademark protection in countries in the well-known mark treatment. The difference of registration systems and difference law vary among countries create some difference treatments among the protection of trademark based on those countries law.

For instance, the Indonesian government, these past few years has made some progress in strengthening intellectual property right protection by enactment of new laws and regulations. Although, Indonesia still faces some problems with the trademark piracy and trademark infringement, especially directed on wellknown mark protection. (Adnan and McGuide, 2008: 207-208)

In the other countries, to protect well-known mark, they set out protection toward defensive mark registration. Defensive mark is defined as trademark widely obtain law enforcement than normal mark and can be used as a basis to claim or sue other goods or services. To receive defensive mark, there must be though basic mark that is well-known mark. Defensive trademark registration system is uncommon in the world, few countries maintain this system. (Thu, 2010: 37)

In Indonesia itself, there is a case on the implementation of defensive mark as well-known mark protection i.e. Kabushiki Kaisha Monteroza $v$ Arifin Siman in jurisdiction of Central Jakarta Commercial Court in 2010 which the plaintiff issued the defensive mark registration as the evidence to prove the famousness of its mark before the court and continued by cassation in Indonesian Supreme Court in 2013. Until this moment, there is no clearly different treatment of well-known and famous mark protection in Indonesia. Well-Known/Famous mark protection in Indonesia is same as normal mark.

By that reason, the author will be discussing on the implementation of Indonesian trademark law and regulation especially on the protection of well-known mark and its possibility and indication to regulate defensive mark as well-known mark protection.

This legal research is focused on two main questions as following:

1. How are regulations towards well-known/famous mark protection according to Indonesian trademark law?

2. How is the legal possibility to regulate defensive mark as well-known mark protection in Indonesia?

Legal Possibility to Regulate Defensive ... 2 


\section{RESEARCH METHODOLOGY}

Type of this research is the normative legal research, meaning that this research will be conceptual and developed based on the positive law namely regulations and doctrines related with well-known mark and defensive mark and then connected with focus problem that discussed by authors. Method of data collecting is by literature studies which includes study on textbooks, literatures, law journals and electronic legal materials, the results of research and other scholars' materials with related to well-known trademark protection in international law and national law especially Indonesia Trademark Law. The research method approach in this research is statutory research approach which is based on the implementation of regulation of trademark law in Indonesia related to well-known mark protection and possibility to regulate defensive mark.

\section{FINDINGS AND DISCUSSIONS}

\section{The Concept of Well-Known Mark, Famous Mark and Normal Mark}

Under legal terminology, there are two kinds of terms indicated the mark with reputation that are famous mark and well-known mark. Some of jurisdiction take famous mark and well-known mark as a same term. Meanwhile the others jurisdiction differentiates between famous mark and well-known marks. (Jened, 2015: 241)

According to Merriam Webster as quoted by Frederic Mostert, the ordinary meaning of well-known is widely known and known to many. (Thu, 2010: 6) Hiroko try to identify the definition of well-known mark as: (Onishi, 2009: 265-266)

"Well-known trademark explicitly included register able trademarks, service business identifiers and domain names. Well-known trade mark concept lies in the consideration of two what extent a mark is well-known which is submitted to relate to relate to distinctiveness ...."

Well-Known mark is mark has high reputation because the sign has a power to attract people so that any type of goods under the brand immediately cause familiar attachment and mythical context to each consumer spheres. This mark has high reputation due to symbolic power to attract attention to consumer so that people have acknowledgement toward those mark.
In the other hands, mark is so widely known that it is categorized as famous mark which the level of famous mark is also higher than a normal mark so the types of goods under this mark will directly cause a touch of familiarity and mythical bond. (Budi Agus Riswandi and M.Syamsudin, 2004: 87). Famous mark also includes as the mark with highest level. Such a famousness around the world in his reputation classified as the world aristocrat mark. Many people are very difficult to distinguish between well-known mark and famous mark. The difficulty in interpretation, resulting obstacle to determine border and size between those marks. (Khairandy, 1999: 70)

\section{The Concept of Defensive Mark.}

In trademark law especially in International Convention there are no exact definitions of defensive mark. Trademark Law Treaty 1994 is only one international treaty that mentioned that defensive mark as one of the special kinds of marks which applied by any state or intergovernmental organization who declare reservation on Trademark Law Treaty 1994. Under article 21 clause (1) of Trademark Law Treaty 1994 mentioned that:" [Special Kinds of Marks] Any State or intergovernmental organization may declare through a reservation that, notwithstanding Article 2(1)(a) and (2)(a), any of the provisions of Articles 3(1) and (2), 5,7, 11 and 13 shall not apply to associated marks, defensive marks or derivative marks. Such reservation shall specify those of the aforementioned provisions to which the reservation relates."

Even in the academic, the problems of definition defensive mark still have contravention. Defensive mark generally defines as the trademark which has been registered for creating a defensive perimeter around the mark used by the proprietor (Sitoris, 2012:21). Defensive trademark is a form of trademark used to prevent trademark infringement.

A defensive trademark can be applied for by a trademark owner of a well-known trademark for goods or services that are not intended to be used by that owner. (https://definitions.uslegal.com). Defensive record is simply an administrative record for limited use within the jurisdiction of the trademark office per se. It is referred to as "defensive" since it serves as an alternative for the mark to being qualified for broader protection in the absence of clear criteria to determine whether a trademark is well-known. (http://www.managingip.com). James B 
Lumenta as quoted by Lily Evelina Sitoris explained that one of the ways to utilize defensive mark is by registered such mark as well-known mark. (Sitoris, 2012: 22) In the other hand, Baker and McKenzie noted that: (www.bakerinfo.com)

"A defensive mark first takes effect upon the completion of a defensive mark registration. On this point, it differs from ordinary trademarks, which exist if trademark registration is not completed."

If a trademark registration only provides protection when a third party uses the mark with respect to goods/services like or the same as the goods/services designated for a registered trademark. Registering regular trademark does not unlimited right to prevent others from using a mark similar or even identical senior mark means that trademark owner only is able to receive protection in respect to the goods and services specified in the application.

A well-known trademark can register a defensive trademark for those goods and services which they have no plans to use, but which nevertheless, may run the risk of being used by third parties to take advantage of the trademark awareness. However, use of the mark by a third party with respect to goods or services different from the goods/services designated for the trademark may cause confusion, dilution or pollution if the trademark is well-known and damage the goodwill that has accrued to the Registered Trademark. The defensive mark system can remedy this weakness in the protection provided by trademark registration. It can thus be said that the defensive registration is used to shield of well-known trademark. (http://www.clarkemodet.com)

In this matter, defensive mark creates a wider protection for a famous mark which can prohibit a third party from using or registering a famous for goods and services but dissimilar to those of famous mark. Defensive mark also became an effective material for make famousness known in a lawsuit abroad or when administrative action is taken. So, the purpose of a defensive trademark registration is to protect a well-known/famous mark beyond the limited scope of an exclusive right established by ordinary trademark registration to use the mark for the designated goods of services. In additional if it is registered as the defensive mark there is also no obligation to use it, so a third party's application or use of an identical is prohibited as far as trademark conflicts with defensive trademark registration (Thu, 2010: 35-38)
These additional goods or services registered as defensive marks need not to be like the original goods or services and the registrant need not use or have any intent to use mark on additional goods or services. (Port, 1997: 270) As the example, NIKE is the registered trademark, it is very well-known there's likely that if someone was to use the trademark on other goods or services like coffee cup then a consumer makes a connection to NIKE's trademark.

A registration of defensive mark usually expires in 10 years from a date of registration, but its term does not synchronize with a term for registration of a famous mark. The registration of defensive mark can be renewable by filing an application but needs examination by an examiner to see if the defensive mark remains satisfying the requirements.

The registration cannot be cancelled unless the primary registration is cancelled, and the trade mark owner does not hold another standard registration for the same trade mark. Enforcing a defensive registration is likely to be more cost effective and certain than an action for infringement of a wellknown trade mark or for passing off or misleading and deceptive conduct. Whilst a trade mark owner will need to prove its reputation to secure defensive registration, this is done at a time when the owner is not facing the stresses and pressures of litigation; it is a more easily managed process.

\section{The Protection of Well-Known and Famous Mark in International Law}

There have been huge efforts to harmonize the protection of well-known marks and to set standards of minimum protection governed by international agreements, regional and bilateral treaties and supranational law (Luepke, 2008: 792). The famous and/or well-known trademark are recognized by two treaties: the Paris Convention for Industrial Property (as revised in Hague at 1925) and the TRIPs Agreement. (Livandarin, 2008: 596). In addition, WIPO as policy maker on international concerning on intellectual property formulated WIPO Joint Recommendation concerning provisions on the protection of well-known marks as the first implementation of WIPO policy to classify, consolidate and supplement of international protection of well-known marks under Paris Convention and the TRIPs Agreement. (Croze, May 
2000: 138) Paris Convention refers to well-known mark in Article 6bis which mentioned:

(1) The countries of the Union undertake, ex officio if their legislation so permits, or at the request of an interested party, to refuse or to cancel the registration, and to prohibit the use, of a trademark which constitutes a reproduction, an imitation, or a translation, liable to create confusion, of a mark considered by the competent authority of the country of registration or use to be well-known in that country as being already the mark of a person entitled to the benefits of this Convention and used for identical or similar goods. These provisions shall also apply when the essential part of the mark constitutes a reproduction of any such well-known mark or an imitation liable to create confusion therewith.

(2) A period of at least five years from the date of registration shall be allowed for requesting the cancellation of such a mark. The countries of the Union may provide for a period within which the prohibition of use must be requested.

(3) No time limit shall be fixed for requesting the cancellation or the prohibition of the use of marks registered or used in bad faith.

According to this article, setting out the obligations of member States to refuse to register, cancel the registration or prohibit the use of a trademark which constitutes a reproduction, an imitation, or a translation, liable to create confusion with a wellknown mark and providing the term within which the owners of well-known trademarks may request that the authorities cancel a registration of an infringing mark. However, it is not clearly defined well-known marks. This article only ground mentioned is the acceptance or recognition of such marks by the authorities of countries in the union or countries in where the mark is used. (Tam, 2011: 56)

TRIPs Agreement which are confirming and extending provision in TRIPs Agreement regulating on the wellknown mark mentioned in article 16 paragraph (2) and paragraph (3) which stated:

(2) Article 6bis of the Paris Convention (1967) shall apply, mutatis mutandis, to services. In determining whether a trademark is well-known, Members shall take account of the knowledge of the trademark in the relevant sector of the public, including knowledge in the Member concerned which has been obtained because of the promotion of the trademark.
(3) Article 6bis of the Paris Convention (1967) shall apply, mutatis mutandis, to goods or services which are not similar to those in respect of which a trademark is registered, provided that use of that trademark in relation to those goods or services would indicate a connection between those goods or services and the owner of the registered trademark and provided that the interests of the owner of the registered trademark are likely to be damaged by such use.

TRIPs Agreement which imposed the rules of the Paris Convention on all WTO member states, established a principle for the determination of when a trademark has become well-known and required members to provide further protection for wellknown marks outside of goods for which the wellknown mark is registered. (Darnton, 2011: 16-17) In other words, TRIPs agreement has also expanded the scope of protected trademark to include trademarks which are very well-known. (Tam, 2011: 57)

Article 16 paragraph (2) contain on the basic standard under which a member states must determine a well-known mark. Importantly, the marks are not required to be known by all of the public in the members state but only by the relevant sector of the public and member states must consider the extent to which the mark has promoted to such members of the public. (Tam, 2011: 19)

Article 16 paragraph (3) expanded the Paris Convention rules on well-known marks to dissimilar goods which in Paris Convention protected wellknown trademarks from other parties who wanted to use the mark on "the same or similar goods."

World Intellectual Property Organization issued Joint Recommendation Concerning Provisions on the protection of well-known marks 1999. WIPO Joint Recommendation Concerning Provision on the Protection of Well-known marks 1999 regulated the formulation about the criteria of a trademark to be categorized as well-known. The competent authority shall consider information submitted to it with respect to factors from which it may be inferred that the mark is, or is not, well-known, including, but not limited to, information concerning the following:

1. the degree of knowledge or recognition of the mark in the relevant sector of the public;

2. the duration, extent and geographical area of any use of the mark; 
3. the duration, extent and geographical area of any promotion of the mark, including advertising or publicity and the presentation, at fairs or exhibitions, of the goods and/or services to which the mark applies;

4. the duration and geographical area of any registrations, and/or any applications for registration, of the mark, to the extent that they reflect use or recognition of the mark;

5. the record of successful enforcement of rights in the mark the extent to which the mark was recognized as well-known by competent authorities;

6. the value associated with the mark.

Besides that, WIPO Joint Recommendation also setting out the provisions on the Scope of WellKnown Marks Protection i.e. The Protection of WellKnown Marks from Bad Faith Registration, Conflicting Marks, Business Identifiers, Conflicting Domain Name.

\section{The Protection of Well-Known Mark in Indonesian Trademark Law}

Indonesian Trademark Law regulated under Law number 20 of 2016 concerning on Marks and Geographical Indication. This law as the amended of the old law i.e. Law no 15 of 2001 concerning on Mark. This law is enacted on October 27th, 2016 and effective into force since February $1^{\text {st }}, 2017$.

Indonesia follows the "first to file" or constitutive systems on the registration of mark which means that the right of mark will be acquired by the mark registration that already registered by owner to Directorate General of Intellectual Property. It is stipulated under article 3 Law no 20 of 2016 on Mark and Geographical Indication which cleared mentioned that "Right of Mark is obtained subsequent to the registration of Mark hereto." Rights of Mark is an exclusive right, which is given by the state to the registered owner of Mark for a certain period by using the Mark personally or by giving permission to other party to use it. Therefore, the filling date of a mark application is very important as it reflects the prior right of the applicant.

Registration creates a registered party are the only parties entitled to a mark and the third-party registrant must respect the right of the first one as it is an absolute right. Those who are not registered will not automatically receive the legal protection. This registration system is a necessary condition for occurrence of mark rights. In other words, the person who registered the mark then he/she the one who was given. The parties granted the legal protection are the parties who registered their mark.

Under Law no. 20 of 2016 on Mark and Geographical Indication, the usage of mark is one of absolute requirement to grant the trademark protection. In the case trademark does not use in the duration of 3 (three) years it will be deleted from the registration of mark. According to article 74 of Law No.20 of 2016 on Mark and Geographical Indication, A deletion of registered Mark may also be filed by third party who has interests in the form of a lawsuit to The Commercial Court by a reasoning of that the Mark hereto has never been used for 3 (three) years consecutively in the trading of goods and/or services since the registration date or the latest utilization. There is also the exception to the unused mark with several reasons there are Import Restriction; Related restriction of goods distribution license which utilizing the related Mark or a temporary decision from an authorized party; or Similar restriction enacted under Governmental Decree.

For the protection of registered well-known mark under article 83 mentioned that owner of a registered mark and/or the licensee of registered mark may file a law suit to the counter party who unrightfully utilizing a mark which has similarity in its essential or its entirety for goods and/or service of the same kind, in a form of: Damages law suit, and/or Termination of all acts that related to the utilization of Mark hereto.

Based on article 21 paragraph (1) Law no 20 of 2016 concerning on Mark and Geographical Indication. Application of mark will be rejected if that mark has similarity or identical with:

1. A registered Mark owned by another party or applied first by another party for goods and/or services of the same kind;

2. Well-known Mark owned by another party for goods and/or services for the same kind;

3. Well-known Mark owned by another party for goods and/or services not of the same kind which complies to requirements; or

4. Registered Geographical Indications.

The article 21 section (1) point $\mathrm{b}$ and c provided the protection to well-known or famous mark owner from the application of mark by other parties which have similarity or identical with those famous mark/well-known mark whether for goods and/or services for the same kind or for goods and/or 
services not for the same kind which fulfill certain requirements.

Article 21 section (1) point $b$ have similar method with the implementation of article 21 section (1) point (a) which contains on the application of refusal if those mark have similar and identical with a registered mark owned by another party or applied first by another party for goods and/or services of the same kind. One of significant differences are wellknown/famous mark that become ground of refusal must not be registered or applied first. In substantive examination, objection document and additional with evidences that submitted in step of announcement from famous/well-known mark owner become main reference of examination to opposing based on Article 21 Par. (1) point (b).

The Elucidation of this Article 21 Par. (1) point b stated the refuse of application which have similarity or identical with well-known/famous mark by another parties for goods and/or services for same kinds conducted by considering the general acknowledgement of public regarding on those mark in relevant business aspect. Besides that, it must consider the reputation of mark that acquired due to rapid and great promotion. In addition, investment in several countries in the world which committed by the well-known/famous mark owner and the mark registration evidences in some countries. If that is not enough, the Commercial Court may order independent institution to implement survey for purposes to acquire conclusion relating on whether the mark is well-known as the ground of refusal.

This law also provides protection for unregistered well-known marks, and against people who have bad faith and attempt to apply for registration of such well-known marks for their own benefits. It is explicitly mentioned in article 76 and its elucidation that stated a lawsuit to annul a registered mark can be filed by an interested party based on the reasons stipulated under article 20 and/or article 21 and owner of unregistered mark may file a lawsuit after he/she applied to the Minister (hereinafter: Ministry of Law and Human Rights). Annulment lawsuit is filed to the Commercial Court against an owner of registered mark. Unregistered mark classifications are Good faith trademark owner which his/her mark has not registered and/or famous/well-known mark, but its mark does not registered.
This law explicitly orders to the mark owner to register its mark due to importance of mark registration in Indonesia against trademark piracy and infringement caused 'bad-faith' registration which often occurred in Indonesia to increase their profits. Bad Faith application exists where a third party or illegitimate owner of mark registers that the mark first in Indonesia, including famous/wellknown mark, thereby preventing the legitimate owner from registering it.

Ministry of Law and Human Rights issued Ministry of Law and Human Rights Regulation (Permenkumham) no 67 of 2016 on Trademark Registrations which set out several main points to be explained under Indonesia's new trademark law system. The regulation is the implementation of article 21 section (4) Law no 20 of 2016 which ordering the advanced regulation on famous/well-known mark in government regulation. This regulation becomes the further explanation from the Law no 20 of 2016 on Mark and Geographical Indication especially of trademark registration and renewal. It also sets out clear criteria for recognition of a well-known mark based on Ministry of Law and Human Right Regulation (Permenkumham).

The criteria on famous/well-known mark is clearly mentioned in this Permenkumham. In order to determine the famous/ well-known mark, it must be conducted by analyzing on the common public acknowledgement on famous/well-known mark in the relevant business fields(Article 18 paragraph (1) Permenkumham No. 67 of 2016 on Mark Registration).Public or society is consumer or society in common who have good relationship on production level, promotion, distribution or marketing towards protected goods and/ services by its relevant famous mark/well-known mark (Article 18 paragraph (2) Permenkumham No. 67 of 2016 on Mark Registration). In order to determine criteria of mark as famous/well-known mark will depend on the following aspects or factors of the mark as follows:

1. Level of knowledge or recognition of the public toward the mark in the concerned business field as famous/well-known mark;

2. Marketing volume of goods and/or service and the acquired profit from the use of concerned mark by its owner;

3. Mark share that is controlled by the mark in the connection with distribution of goods and/or services in society; 
4. Geographical coverage of mark's use;

5. Duration of mark use;

6. Mark promotion and intensity, including investment values used for its promotion;

7. Mark registration or application in other countries;

8. Level of success of law enforcement in mark field, especially regard on mark recognition as wellknown/famous mark by competent authority; or

9. Inherent value of the mark acquired due to its reputation and quality assurance of goods or services protected by mark.

a. (Article 18 paragraph (3) Permenkumham No. 67 of 2016 on Mark registration)

The refusal of mark registration due to have similarity or identical with famous/well-known mark owned by other party for similar and dissimilar goods and/or services in substantive examination may be conducted if it is fulfilling two main requirements. Firstly, famous/well-known mark must submit opposition towards mark registration in announcement step. The opposition must contain sufficient reason and evidence to become burden of proof that mark owned by opposite petitioner is famous/well-known mark and application or mark registration of other party have similarity or identical with mark owned by opposite petitioner. Secondly, mark of opposite petitioner is famous/well-known mark which is registered. (Article 19 Permenkumham No. 67 of 2016 on Mark Registration)

The Legal Possibility of Defensive Mark as WellKnown Mark Protection in Indonesia.

The problem of the protection of well-known/famous mark in Indonesia is controversial issues. There are several practices of protection of well-known mark in several countries that cannot be implemented in Indonesia such as the implementation of defensive mark as legal protection to well-known mark and/or famous mark in Indonesia.

It is reflected by the case of Kabusihiki Kaisha Monteroza v Arifin Siman. Disputed Trademark in this case are Case was happened on jurisdiction of Commercial Court Central Jakarta which happened on December 26th, 2012. Kabushiki Kaisha Monteroza as the owner of WARA-WARA and SHIROKIYA intended to register the mark to Mark directorate. DGIP of Ministry of Law and Human Rights, Nevertheless, the mark registration was rejected by DGIP due to the Mark of WARA-WARA and SHIROKIYA has been registered by Arifin Siman with same trademark i.e. WARA-WARA and SHIROKIYA in DGIP in Indonesia.
Figure 01

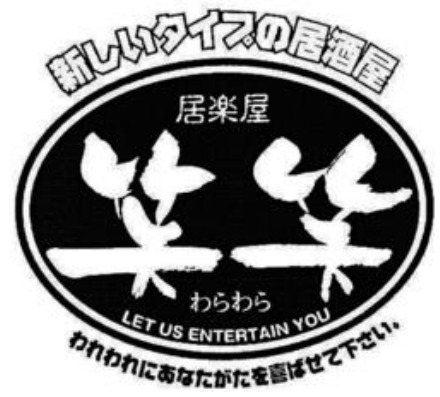

Figure 02

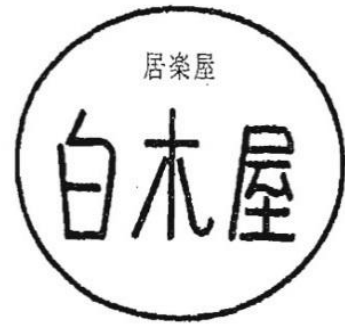

(Figure 01: Plaintiff's Mark entitled as WARA-WARA which registered as Defensive trademark)

(Figure 02: Plaintiff's mark entitled as SHIROKIYA)
Figure 03

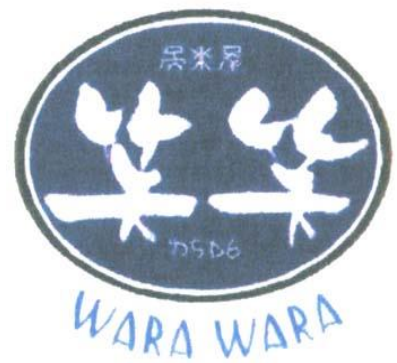

Figure 04

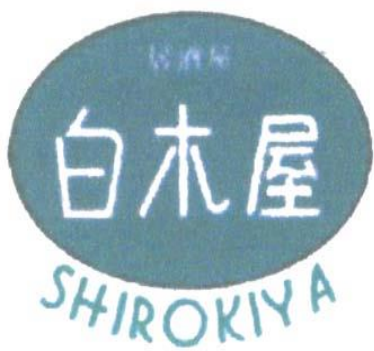

(Figure 03: Defendant's Mark entitled as WARAWARA)

(Figure 04: Defendant's Mark entitled as SHIROKIYA)

Trademark registration of WARA-WARA and SHIROKIYA cannot be implemented in Indonesia due to the existence of the registration of Arifin Siman. Meanwhile in Japan, Kabushiki Kaisha Monteroza's trademark already registered by registration of defensive mark by register number 4185167. In which that registration become the evidences in the court. To obtain defensive mark, it must be the strong senior mark who already known as famous mark. In other words, the well-known mark is already wellknown in Japan, by obtain defensive mark. The Commercial court of Central Jakarta No. 90/Merek/2012 /PN. NIAGA JKT.PST. Panel of Judge rejected the lawsuit of Kabushiki Kaisha Monteroza for all (Menolak gugatan penggugat untuk seluruhnya). Meanwhile in 2013, Kabushiki Kaisha Monteroza issued cessation due to unsatisfied with judge's verdict. The Supreme Court decision number 
491K/Pdt.Sus-HKI/2013 declared "Menolak permohonan kasasi dari Pemohon Kasasi" and also there is no dissenting opinion on this verdict.

The mark of WARA-WARA registered as Defensive Mark and SHIROKIYA cannot be protected as wellknown mark in Indonesia. Principally, the mark protection is territorial rights except by registration toward Madrid Protocol systems, so to protect the mark it must be registration in Indonesia.

In Indonesia, to determine whether the mark is famous/well-known mark in other method is based on the Court Decision. Furthermore, DGIP will follow that decision and adjust that mark is well-known mark. In this case, the court decision in Indonesia refused the famousness of that mark, and it cannot be considered as well-known mark based on DGIP perspective and cannot obtained the legal protection in Indonesia.

According to Panji Wiratmoko (2018) as Informant, the provision and elucidation of article 21 of Law no 20 of 2016 on Mark and Geographical Indication especially concerning on well-known mark provision, there are some weakness as follows as:

1. There is no specific provision of the process or procedure or the development of ordinary mark become well-known mark or famous mark;

2. The registration of mark does not consideration whether the mark is well-known / famous mark or not;

3. There is no specific registration of well-known mark or famous mark even though in trademark law become basis of refusal of mark registration.

4. There is not access in DGIP website of well-known mark database.

According to Lily Evelina Sitoris, the protection of defensive mark has more advantages than the protection of mark from unfair competition or passing off action and the ordinary mark protection. In the unfair competition action especially in Japan, if there is lawsuit it must be provided evidences to prove the reputation, misrepresentation and damages of trademark as one of requirements in the dispute settlement on the passing off action. Meanwhile, by the existences of defensive mark which already registered in authorized institution, if there is dispute so that, by submit the defensive mark evidences which help the mark owner. The benefits, defensive mark as follows: (Sitoris, 2012: 21)
1. Customs rules allow for temporary fixing of imported goods that violate mark rules. This provisional appointment is not made through unfair business competition law but may be possible in a defensive mark system;

2. Rules of unhealthy business competition does not set criminal sanctions against violations of wellknown marks. It can only be done on a popular brand that is proven to cause confusion in its use therefore it is very difficult to crack down on criminal rules but for defensive marks, the criminal code is complete.

In addition, the author argues that, there are some other benefits to using defensive mark if it is implemented in Indonesia as follows:

1. By the implementation of defensive mark in Indonesia, so that the indicator on well-known mark or famous mark will be more obvious due to registering a mark as defensive mark, the mark should be required well-known mark and also may become evidence before the court. In other words, the defensive mark owner is well-known mark owner.

2. Defensive mark provides the means of legally asseting the famousness of trademarks in Indonesia, not only by civil action but also criminal law enforcement.

3. The facilitation or the eassieness to be given to well-known mark owner especially to the forign mark that want to registerd thiier mark in Indonesia in which those foreign mark is recognized as well-known mark as well-known mark owner in Indonesia.

4. The defensive mark will give more prevention of trademark infringement and mark dilution and counterfieitng in Indonesia.

Nevertheless, beside the benefit, there is also disavantanges, if the defensive mark implemented in Indonesia such as there will be much of criminzalitaiton toward local mark which infringed the defensive mark of well-known mark owner from foreign well-known and/or local well-known mark which will become the obstacle to business actor of Indonesia to be developed. There are several factors that will become obstacle to regulating the defensive mark in Indonesia.

1. By the lack of acknowledge of small business actors of Indonesa regarding on the defensive mark, Indonesian will be inclined to regulated ordinary mark rather than regulated defensive 
mark, so that defensive mark registration by Indonesian business actors will be useless

2. The readiness of mark onwer in Indonesia is still low in order to managed their mark so this also created the defensive mark will be useless

3. Not many marks in Indonesia that have been considered as a well-known mark and registered in WIPO International Bearau make the factor inhibiting the application of defensive mark in Indonesia.

According to Nova Susanti, Indonesia is not recognized and known the terms of defensive mark as protection of mark indicated that there are no provisions who mentioned exactly or chapter concerning on defensive trademark. Nevertheless, inderictly the legal protection maybe observed by the existence or the accomodation of right of well-known mark right in law enforcement. As mentioned in article 83 paragraph (2) which indicating that the well-known mark owner may issued lawsuit before the court. Again, in the determination of well-known mark in Indonesia, she said it must be a judge's decision to determine the well-known. She also mentioned that, in article 21 paragraph (1) point b and c Law no 20 of 2016 also, there is ground of refusal toward the unsame kinds of goods and/or services. (Nova Susanti, Interview, 2018.)

Defensive mark, according to her, is for the criminal law enforcement, again indirectly the criminal provision is already exist in the Indonesian trademark law i.e in article 100 of Law No 20 of 2016 on Mark and Geographical Indication. In article 100 is material law in nature, which means the protection of mark by criminal law enforcement is only issued by registered mark and not for unregistered mark. The well-known mark which already registered as long as there is judge verdicts and report to the invetigator. And also maybe issued the damages claim as civil action as mentioned in article 83 Law no 20 of 2016. (Nova Susanti, Interview, 2018.)

According to author, the usage of defensive mark in Indonesia gives more monopoly right and is justified under Competition and Anti-Monopoly Law of Indonesia. This monopoly right might have positive or negative implication. The positive implication is legal certainty and justice to the defensive mark holder as well-known mark owner especially foreign wellknown mark. In the other hand, negative implication to local owner or small business actor who have lack of awareness on their mark and the legal protection of mark, in which using the mark that have similarity or identical with well-known mark that will be claimed and criminalized by defensive mark holder that will be impacted to the obstacle to their innovation and block to development of their business activities.

To consider whether or not the defensive mark may be registered in Indonesia, if the government of Indonesia want to include defensive mark in positive law in Indonesia, according to the author the government must pay attention the justice and legal certainty to all of parties include the local mark and also foreign mark. The formulation of legal norms should be considering also the aspect of Juridical, philosophical and sociology of the people. Due to, in the essence the creation of legal norms also must be needed the aspect of legal necessary of the people.

As mentioned by Deddy Effendy Anakottapary as one of the respondents. He agreed if the defensive trademark is regulated in Indonesia by the reason of marks which come from the Indonesia will be raised and there will be power to raise for the compete with the foreign mark as long as the local mark is ready to compete and acceptance by the people. The problem in Indonesia is local products lack to be accepted in the local market. It becomes dilemma in Indonesia nowadays. Meanwhile foreign products that market in Indonesia, even accepted by local market.

The local business actors in Indonesia have lack to invest their business to foreign and manufacture the product in the foreign country. The defensive mark implementation may be realized in condition that the local mark is already known. By the registration of defensive mark, the scope of legal protection will be broader that the usual mark. He also argued to government and stakeholder to more encourage the people of Indonesia to love local product and providing more socialization on the mark benefit to local business actor in Indonesia and increasing the IPR awareness of the local business actors to Indonesia. (Deddy Effendy, Interview, 2018)

Besides that, according to author if government intends to include the provision of defensive mark in positive law in Indonesia, government should give priority to people interest and the economic development of Indonesian society and the Intellectual Property awareness must be increased. To formulate the defensive mark as one of technical provision especially relating with the protection of well-known mark, the government also must conduct 
research and comparative studies how the other states utilize the defensive mark as well-known mark protection if the defensive mark will be realized. Besides that, all of trademark infringement, trademark piracy, counterfeiting and dilution of mark that conducted by Indonesian business actors should be decrease by the increasing the innovation and IPR awareness of Indonesian society.

The existence of defensive mark in Indonesia, trademark piracy, trademark counterfeiting and unfair competition practice relating to mark especially well-known mark and famous mark can be decreased. The defensive mark registration become one of the solutions of the problem relating to the mark as mentioned, and defensive mark can be one of ground of refusal to mark who violated and infringed well-known mark registered as defensive mark.

Under International Law, defensive mark is only regulated under Trademark Law Treaty 1994 article 21 which defensive mark is classified as special kinds of mark which the state members or intergovernmental organization conduct reservation those treaty. Meanwhile in Indonesia, Indonesia ratified Trademark Law Treaty 1994 by Keputusan Presiden No. 17 of 1997. It is become the obstacle in the enactment of technical regulation on the defensive mark in Indonesia. Due to the legal obligation of Indonesia to follow in implication of all the provision of Trademark Law Treaty 1994 so the legal possibility to regulated defensive mark in legal system in Indonesia is hard to be implemented. Nevertheless, if there are some condition relate to the urgency of defensive mark in Indonesia to be implemented and regulated in Indonesia.

From the explanation above, in this matter, it is hard to implement defensive mark nowadays in Indonesia. The trademark law in Indonesia is still new. To regulate defensive mark must be considering how the implication and also the legal needs and its development in the future. Whether or not it will be important to regulate or not. However, for several years or in the present, the defensive mark may be needed and it is important to be regulated in Indonesia by the existence of business development and incrasing of well-known mark comes from local mark or foreign mark. Intelletual Property is the subject that fast in its development.

Finally, whether Trademark law able to accomodate the all the need of legal problem or not in Indonesia, especially in Indonesia. It is not possible to be implemented. Maybe defensive mark will be one of the choices to be regulated in the formulation of trademark law in Indonesia in the future. In addition, to regulate the defensive mark in Indonesia should consider number of local marks that are already wellknown mark and recognized mark in international society and also the local mark must take risk on the law enforcement by criminal punishment or civil action by the existence of defensive mark regulation in future.

\section{CONCLUSION}

The protection of well-known mark and famous mark is regulated in International law especially in Paris Convention on Industryial Property and TRIPs Agreement. WIPO enacted WIPO Joint Recommendation concerning on Provisions on the protection of well-known mark to consolidate the international protection of well-known mark and famous mark. The states may set out the protection of well-known mark and famous mark based on its national law especially in the definition and the criteria of well-known mark itself depends on the national law. In Indonesia, trademark protection is based on the principle of "first to file". Defensive mark is not regulated and recognized under the trademark law of Indonesia. In here, Indonesia still has insufficient protection in the law due to strict protection that does not cover all the law protection toward some kinds of trademark violations happened. It is reflected that Indonesian still lacked protection toward their mark. The unrecognized defensive mark is reflected in case of Kabushiki Kaisha Monteroza $v$ Arifin Siman which the judges' verdict did not consider defensive mark as the reflection of wellknown mark. Then, Indonesian trademark registration of well-known mark and famous mark considers as same as with the ordinary mark. Therefore, the defensive mark that comes from foreign countries that want to be protected in Indonesia must be registered as ordinary mark. Nevertheless, the defensive mark in Indonesia indirectly may be observed by the accommodation of well-known mark right in law enforcement in Indonesia such article 83 paragraph (2), article 21 paragraph (2) point $\mathrm{b}$ and $\mathrm{c}$ and the criminal provision in the article 100 Law No.20 of 2016 and article 19 paragraph (2) point a and b Permenkumham No. 67 of 2016. 


\section{REFERENCES}

Adnan, Zain., \& McGuide, Brett. (2008). Indonesia Progress in IP Protection-But Much Still to be Done. Jakarta: Rouse \& Co International.

Baker \& McKenzie. Japan How to Use Defensive mark. www.bakerinfo.com

Collin, Craig. (2014). Intellectual Property. Australia: Lexis Nexis.

Croze, Denis. (2000). Protectiion of Well-Known Marks. Journal of Intellectual Property Rights, 3, 138.

Darnton, James E. (2011). The Coming of Age of The Global Trademark: The Effect of TRIPs on the WellKnown Marks Exception to The Principle of Territoriality. Michigan State International Law Review Sysmposium.

Jened, Rahmi. (2015). Hukum Merek (Trademark Law) Dalam Era Global dan Inegrasi Ekonomi. Jakarta: PT Kharisma Putra Utama.

Khairandy, Ridwan. (1999). Perlindungan Hukum Merek Terkenal di Indonesia. Jurnal Hukum, 6, 6, 70.

Luepke, Marcuus. H.H. (2008). Taking Unfair Advantage or Diluting a Famous Mark -A 20/20 Perspective on the Blurred Differences between U.S. and E.U. Dilution Law, 98, 3.

Mostert, Frederick. W. (1997). Famous and WellKnown Marks. United Kingdom: Butterworths.

Onishi, Hiroko. (2009). Well-Known Trademark Protection: Confusion in EU and Japan. Southampton: University of Southampton.

Port, Kenneth L. (1997). Protection of Famous Trademark in Japan and United States. Wisconsin International Journal, 15, 2.

Riswandi, Budi Agus., \& Syamsudin, M. (2004). Hak Kekayaan Intelektual dan Budaya Hukum. Jakarta: PT.Raja Grafindo Persada.

Rizaldi, Julius. (2009). Perlindungan Kemasan Produk Merek Terkenal Terhadap Persaingan Curang. Bandung: PT Alumni.
Sitoris, Lily Evalina. (2012). Defensive Mark Sebagai Aset Merek. Media HKI, 8, 21-22.

Tam, Phan Ngoc. (2011). Well- Known Trademark Protection, A Comparative Study Between the Laws of European Union and Vietnam. Doctoral Dissertation of The Field of Study: International and Comparative Law: Faculty of Law Lund University.

\section{Law and Regulation}

Paris Convention for Industrial Properties

Trademark Law Treaty 1994

TRIPs Agreement

WIPO Joint Recommendation Concerning on Provision of the Protection of Well-Known marks Law No. 20 of 2016 concerning on Marks and Geographical Indication

Supreme Court Verdict (Cessation decision) Number 491 K / Pdt.Sus-HKI/2013 